\title{
Involvement of the rapamycin-sensitive pathway in the insulin regulation of muscle protein synthesis in streptozotocin-diabetic rats
}

\author{
K Grzelkowska $^{1,2}$, D Dardevet ${ }^{1}$, M Balage ${ }^{1}$ and J Grizard ${ }^{1}$ \\ ${ }^{1}$ Unité d’Etude du Métabolisme Azoté, Institut National de la Recherche Agronomique, 63122 Ceyrat, France \\ ${ }^{2}$ Department of Animal Physiology, Veterinary Faculty, Warsaw Agricultural University, 02-787 Warsaw, Poland \\ (Requests for offprints should be addressed to K Grzelkowska, Department of Animal Physiology, Veterinary Faculty, Warsaw Agricultural University, \\ Nowoursynowska 166, 02-787 Warsaw, Poland)
}

\begin{abstract}
Insulin resistance in 3-day streptozotocin (STZ)-treated rats was manifested by the lack of antiproteolytic action of insulin as well as by a reduction of its stimulatory effect on protein synthesis $(-60 \%$ compared with the control group) in epitrochlearis muscle incubated in vitro. In the present study, we have investigated the diabetes-associated alterations in the insulin signalling cascade, especially the phosphatidylinositol-3 kinase (PI-3 kinase)/p70 S6 kinase $\left(\mathrm{p} 70^{\mathrm{S} 6 \mathrm{~K}}\right)$ pathway, in rat skeletal muscle. LY 294002, a specific inhibitor of PI-3 kinase, markedly decreased the basal rate of protein synthesis and completely prevented insulin-mediated stimulation of this process both in control and diabetic rats. Thus, PI-3 kinase is required for insulin-stimulated muscle protein synthesis in diabetic rats as in the controls. Rapamycin, an inhibitor of mammalian
\end{abstract}

target of rapamycin (mTOR), had no effect on the basal rate of protein synthesis in either of the experimental groups. In control rats, the stimulatory action of insulin on muscle protein synthesis was diminished by $36 \%$ in the presence of rapamycin, whereas in diabetic muscles this reduction amounted to $68 \%$. The rapamycin-sensitive pathway makes a relatively greater contribution to the stimulatory effect of insulin on muscle protein synthesis in diabetic rats compared with the controls, due presumably to the preferential decrease in the rapamycin-insensitive component of protein synthesis. Neither basal nor insulinstimulated $\mathrm{p} 70^{\mathrm{S} 6 \mathrm{~K}}$ activity, a signalling element lying downstream of mTOR, were modified by STZ-diabetes. Journal of Endocrinology (1999) 160, 137-145

\section{Introduction}

A characteristic feature of uncontrolled diabetes mellitus is the decrease in body weight and marked muscle atrophy. This net loss of body protein results from both an increase in proteolysis and a decrease in protein synthesis. Enhanced protein breakdown has been described in skeletal muscle of rats with experimentally-induced diabetes (Pepato et al. 1996, Bailey et al. 1997) as well as in type 1 diabetic patients (reviewed in Tessari et al. 1992). The inhibition of elevated proteolysis in diabetic humans requires higher plasma insulin levels than those normally occurring in vivo (Tessari et al. 1992), which reflects an insensitivity to the antiproteolytic effect of insulin. In numerous studies performed in vivo (Pain \& Garlick 1974, Odedra et al. 1982, Pain et al. 1983, Karinch et al. 1993), and on perfused muscle preparations (Flaim et al. 1980, Williams et al. 1980), insulin treatment only partially restored an impaired protein synthesis in diabetic rats, further suggesting alterations of the action of this hormone on muscle protein synthesis. Taken together these data clearly indicate that insulin resistance with respect to protein metabolism may contribute, along with insulin deficiency per se, to the loss of muscle protein in diabetic subjects.

There has been much recent progress in the elucidation of the signalling cascade acting downstream of the insulin receptor. A critical event is the activation of the insulin receptor tyrosine kinase and resultant phosphorylation of insulin receptor substrate-1 (IRS-1) (White \& Kahn 1994). This leads to the recruitment of several further signalling components such as phosphatidylinositol-3 kinase (PI-3 kinase), ras, and the tyrosine phosphatase SHPTP2 which, in turn, trigger multiple effector pathways. Although the mechanism of insulin action on skeletal muscle metabolism is not exactly defined, several lines of evidence point to the role of PI-3 kinase and the pathway including $\mathrm{p} 70 \mathrm{~S} 6$ kinase $\left(\mathrm{p} 70^{\mathrm{S} 6 \mathrm{~K}}\right)$. It has been demonstrated that PI-3 kinase is required for insulinregulated glucose uptake (Le Marchand-Brustel et al. 1995, Jullien et al. 1996), glycogen synthesis (Shepherd et al. 1997), as well as protein synthesis and proteolysis (Dardevet et al. 1996). p70 ${ }^{\mathrm{S} 6 \mathrm{~K}}$ is usually regarded as one of the intermediates situated downstream of PI-3 kinase 
(Chung et al. 1994) on the pathway implicated in the stimulation of muscle protein synthesis (Dardevet et al. 1996).

In parallel to the investigation of the insulin signalling cascade in skeletal muscle, analysis of the possible defects leading to insulin resistance has recently been developed. Decreased autophosphorylation of the receptor kinase, previously proposed as the most straightforward explanation for the insulin resistance (Kadowaki et al. 1984, Block et al. 1991), seems to have limited biological significance in view of the increased insulin binding to various tissues of insulinopaenic diabetic rats (reviewed in Sechi et al. 1992). Moreover, the early postreceptor events e.g. IRS-1 protein content and its phosphorylation in response to insulin were not impaired during diabetes (Giorgino et al. 1992, Saad et al. 1992). Molecular defects leading to insulin resistance may therefore involve more distal steps in the insulin signalling cascade.

In the present study we have examined the possible contribution of the PI-3 kinase $/ \mathrm{p} 70^{\mathrm{S} 6 \mathrm{~K}}$ pathway to the insulin resistance of skeletal muscle protein turnover in streptozotocin-diabetic rats. We have investigated the effect of LY 294002 and rapamycin, specific inhibitors of $\mathrm{PI}-3$ kinase and $\mathrm{p} 70^{\mathrm{S} 6 \mathrm{~K}}$ respectively, on insulin action in epitrochlearis muscle in vitro. The activity of $\mathrm{p} 70^{\mathrm{S} 6 \mathrm{~K}}$ was also analysed.

\section{Materials and Methods}

\section{Chemicals}

$\mathrm{L}-\left[\mathrm{U}-{ }^{14} \mathrm{C}\right]$ phenylalanine $(450 \mathrm{mCi} / \mathrm{mmol})$ and $\left[\gamma^{32} \mathrm{P}\right] \mathrm{ATP}$ $(3000 \mathrm{Ci} / \mathrm{mmol})$ were obtained from Amersham (Aylesbury, Bucks, UK). Porcine insulin was supplied by Novo (Bagsvaerd, Denmark).

Long-acting Lente MC insulin (a mixture of porcine and bovine insulin) and Ultratard HMge human insulin were obtained from Novo Nordisk Pharmaceutique SA (Boulogne, France). Rabbit polyclonal anti-p $70^{\mathrm{S} 6 \mathrm{~K}}$ antibody was purchased from Santa Cruz Biotechnology (Santa Cruz, CA, USA). Streptozotocin and other chemicals were supplied by Sigma Chemical Co. (St Louis, MO, USA). Rapamycin (ICN, Costa Mesa, CA, USA) and LY 294002 (Tebu, Le Peray en Yvelines, France) were dissolved in dimethyl sulphoxide (DMSO) and stored at $-20{ }^{\circ} \mathrm{C}$.

Plasma insulin was determined by direct radioimmunoassay with a commercial kit (ERIA Diagnostic Pasteur, Sanofi, France), according to the manufacturer's protocol. Protein content was assayed by the bicinchoninic acid (BCA, Pierce Chemical Co., Rockford, IL, USA) or Bradford (Bio-Rad, Richmond, CA, USA) reaction.

\section{Animal procedure}

These experiments were carried out in accordance with current legislation on animal experiments in France.
Young (4-week-old) male Sprague-Dawley rats were purchased from IFFA-Credo (L'Arbresle, France) and housed under controlled environmental conditions (temperature $22^{\circ} \mathrm{C}, 12-\mathrm{h}$ darkness period starting at $1800 \mathrm{~h}$ ). Animals were given free access to water and standard laboratory chow diet 3-4 days before the beginning of the experiment. Diabetes was induced with streptozotocin (STZ) dissolved in $0.01 \mathrm{M}$ citrate buffer, $\mathrm{pH} 4.5$, administered intravenously in a single dose of $110 \mathrm{mg} / \mathrm{kg}$, at 0900-1000 h, to overnight-fasted rats. Control animals received an equal volume of vehicle. All animals were returned to ad libitum feeding conditions $6 \mathrm{~h}$ after injection. Glycosuria was verified by Clinistix (Bayer Diagnostics, Puteau, France) the following morning and was $3+$ (i.e. high on arbitrary scale) in STZ-treated rats. Preliminary observations have shown that the maximum effect of diabetes on protein turnover in skeletal muscle (e.g. insulin resistance of protein synthesis and degradation in vitro) occurred three days after STZ injection (data not shown). This time was therefore chosen for further experimental procedures. Rats were killed under anaesthesia with sodium pentobarbital $(6.0 \mathrm{mg} / 100 \mathrm{~g}$ body weight) after an overnight fast. Epitrochlearis muscles were dissected intact for incubation (see below). Blood was drawn from the aorta to determine the plasma glucose and insulin levels.

\section{Assessment of protein metabolism}

Muscle incubation was performed in Krebs-Hensleit buffer (KHB) $(120 \mathrm{mM} \mathrm{NaCl}, 4.8 \mathrm{mM} \mathrm{KCl}, 25 \mathrm{mM}$ $\mathrm{NaHCO}_{3}, \quad 2.5 \mathrm{mM} \quad \mathrm{CaCl}_{2}, \quad 1.2 \mathrm{mM} \quad \mathrm{KH}_{2} \mathrm{PO}_{4}$, and $1.2 \mathrm{mM} \mathrm{MgSO}_{4}, \mathrm{pH} 7 \cdot 4$ ) supplemented with $5 \mathrm{mM}$ HEPES, $5 \mathrm{mM}$ glucose, $0 \cdot 1 \%$ BSA (99\% fatty acid free), $0.17 \mathrm{mM}$ leucine, $0.20 \mathrm{mM}$ valine, $0.10 \mathrm{mM}$ isoleucine, and saturated with $95 \% \mathrm{O}_{2} / 5 \% \mathrm{CO}_{2}$ gas mixture. Epitrochlearis muscles were preincubated for $30 \mathrm{~min}$ in $\mathrm{KHB}$ supplemented with $100 \mu \mathrm{M}$ LY 294002 or $200 \mathrm{nM}$ rapamycin, and then transferred for a further $3 \mathrm{~h}$ into fresh medium of the same composition, without or with $30 \mathrm{nM}$ insulin (corresponding to approx $4 \mathrm{mU} / \mathrm{ml}$ ). This dose of insulin has already been shown to exert a maximal stimulatory effect on protein synthesis in rat epitrochlearis muscle incubated in vitro (Dardevet et al. 1994). The appropriate controls with the diluent of the inhibitors (DMSO, final concentration 0.01\%) were also performed. Incubation medium was changed at $1-\mathrm{h}$ intervals. In order to measure the rate of protein synthesis, $0.5 \mathrm{mM}$ L-[U- $\left.{ }^{14} \mathrm{C}\right]$ phenylalanine $(0 \cdot 15 \mu \mathrm{Ci} / \mathrm{ml})$ was added to the medium during the last hour of incubation. Since antiproteolytic action of insulin on epitrochlearis muscle in vitro requires prolonged treatment with the hormone (Stirewalt \& Low 1983), in the third hour of incubation it was possible to measure both protein synthesis and protein breakdown in the same muscle preparations. Previous observations showed that rat epitrochlearis muscle maintained linear rates of protein synthesis for $3 \mathrm{~h}$ of incubation 
(see above and D Dardevet, unpublished observations). At the end of the incubation muscles were blotted and homogenized in 10\% trichloroacetic acid (TCA). TCAprecipitated material was washed three times with $10 \%$ TCA and solubilized in $1 \mathrm{M} \mathrm{NaOH}$ at $37^{\circ} \mathrm{C}$. These extracts were used for the estimation of protein content as well as the radioactivity incorporated into muscle proteins. The rate of protein synthesis was expressed as nanomoles phenylalanine $(\mathrm{Phe}) / \mathrm{mg}$ protein.h. Protein degradation was determined as described in detail by Tischler et al. (1982). Briefly, since tyrosine is neither synthesized nor degraded in skeletal muscle (discussed in Fulks et al. 1975), the appearance of this amino acid in the medium provides a measure of net protein breakdown. Re-utilization of tyrosine was estimated from the rate of protein synthesis by using the ratio of tyrosine/phenylalanine content in total muscle protein $(0 \cdot 77)$. The rate of muscle protein degradation was therefore calculated as follows: total proteolysis (nanomoles $\mathrm{Tyr} / \mathrm{mg}$ protein.h) $=\left(\right.$ incorporation of $\left[{ }^{14} \mathrm{C}\right]$ Phe into protein) $(0 \cdot 77)+$ (release of tyrosine into the medium). It should be noted that incubated muscles in vitro are in a negative nitrogen balance, with protein breakdown rates exceeding protein synthesis rates, even in the presence of insulin. Under these conditions the pool of intracellular amino acids resulting from protein degradation and supplying the precursors for new proteins is rather unlikely to limit the rate of protein synthesis.

\section{Measurement of $p 70^{\text {S6K }}$ activity}

Epitrochlearis muscles were preincubated for $30 \mathrm{~min}$ in $\mathrm{KHB}$ and transferred into fresh medium without or with insulin $(30 \mathrm{nM})$ for a further $20 \mathrm{~min}$. Afterwards, muscles were homogenized in ice-cold extraction buffer $(50 \mathrm{mM}$ Tris-acetate, $50 \mathrm{mM}$ NaF, $2.5 \mathrm{mM}$ EDTA, $1 \mathrm{mM}$ EGTA, $5 \mathrm{mM}$ sodium pyrophosphate, $5 \mathrm{mM} \quad \beta$ glycerophosphate, $1 \mathrm{mM} \mathrm{Na} \mathrm{VO}_{4}, 2 \mathrm{mM}$ dithiothreitol (DTT), $1 \mathrm{mM}$ benzamidine, $4 \mu \mathrm{g}$ leupeptin, and $0 \cdot 1 \%$ Triton X-100, pH 7.2) and centrifuged at $10000 \mathrm{~g}$ for $15 \mathrm{~min}$ at $4{ }^{\circ} \mathrm{C}$. The activity of $\mathrm{p} 70^{\mathrm{S} 6 \mathrm{~K}}$ was measured by an immune complex kinase assay. Briefly, aliquots of supernatant containing $100 \mu \mathrm{g}$ total protein were incubated for $4 \mathrm{~h}$ at $4{ }^{\circ} \mathrm{C}$ with $3 \mu \mathrm{l}$ p $70^{\mathrm{S} 6 \mathrm{~K}}$ antibody preadsorbed to protein A-agarose beads. The immune complexes were collected by centrifugation, washed three times with kinase assay buffer $\left(25 \mathrm{mM}\right.$ MOPS, $15 \mathrm{mM} \mathrm{MgCl}_{2}$, $1 \mathrm{mM}$ DTT, $0 \cdot 1 \% \mathrm{BSA}, \mathrm{pH} 7 \cdot 2$ ) and then resuspended in the same buffer supplemented with $2 \mu \mathrm{M}$ inhibitory peptide of cAMP-dependent protein kinase, $0 \cdot 1 \mathrm{mM}$ S6 peptide (RRRLSSLRA) and $100 \mu \mathrm{M} \quad\left[\gamma_{-}{ }^{32} \mathrm{P}\right] \mathrm{ATP}$ (specific activity 3000 d.p.m./pmol). The reaction was conducted for $40 \mathrm{~min}$ at $30^{\circ} \mathrm{C}$ and was terminated by adding $50 \mathrm{mM}$ unlabelled ATP. The reaction contents were spotted onto phosphocellulose filter paper (Whatman P-81) and washed three times with $75 \mathrm{mM}$ phosphoric acid prior to counting in a $\beta$-scintillation counter. Pilot experiments showed that under these conditions, the incorporation of ${ }^{32} \mathrm{P}$ into S6 peptide is linear and proportional to the amount of proteins used $(100-200 \mu \mathrm{g})$.

\section{Western blotting}

Equal amounts of muscle protein $(25 \mu \mathrm{g})$ were subjected to SDS-PAGE under reducing conditions. Electrotransfer of proteins to nylon membranes (Millipore Corp., Bedford, MA, USA) was carried out for $1 \mathrm{~h}$ at $100 \mathrm{~V}$, followed by blocking in TBS buffer $(20 \mathrm{mM}$ Tris, $500 \mathrm{mM} \mathrm{NaCl}$, $\mathrm{pH} 7 \cdot 5$ ) supplemented with $5 \%$ nonfat powdered milk. Membranes were then probed with primary antibody $(1 \mu \mathrm{g} / \mathrm{ml})$ for $16 \mathrm{~h}$ at $4{ }^{\circ} \mathrm{C}$, washed three times in TBS containing $0.05 \%$ Tween-20 and were incubated with goat anti-rabbit antibody conjugated with horseradish peroxidase. The blots were developed using the enhanced chemiluminescence (ECL) detection system (Amersham) according to the manufacturer's protocol.

\section{Statistical analysis}

The data were expressed as means \pm S.E.M. The results were statistically evaluated using ANOVA. Values of $P<0 \cdot 05$ were considered significant.

\section{Results}

\section{Animal characteristics}

STZ-treated rats lost on average $5 \mathrm{~g} /$ day in body weight over the study period, whereas rats in the control group gained approximately $6 \mathrm{~g} /$ day. At the end of the experiment, the plasma insulin level in STZ-treated rats was markedly reduced when compared with the control group $(10 \cdot 3 \pm 0 \cdot 6$ vs $32 \cdot 1 \pm 3 \cdot 0 \mu \mathrm{U} / \mathrm{ml}, P<0 \cdot 05)$. This drop in the insulin level in diabetic rats was accompanied by a 4 -fold increase in fasting plasma glucose $(32 \cdot 1 \pm 1 \cdot 4$ vs $7 \cdot 7 \pm 0.2 \mathrm{mmol} / 1$ for diabetic and control rats respectively, $P<0 \cdot 05)$. Diabetic rats exhibited a marked muscle atrophy reflected by a reduction in the weight of epitrochlearis $(21.5 \pm 0.6$ vs $16.2 \pm 0.5 \mathrm{mg}$ for control and diabetic rats respectively, $P<0 \cdot 05)$ and gastrocnemius $(734 \cdot 2 \pm 16 \cdot 2$ vs $528 \cdot 4 \pm 26 \cdot 2 \mathrm{mg}$ for control and diabetic rats respectively, $P<0 \cdot 05)$ muscle.

\section{Effect of LY 294002 on insulin-regulated muscle protein turnover}

Treatment of the epitrochlearis muscles taken from control rats with insulin caused a significant increase in the rate of protein synthesis $(0 \cdot 274 \pm 0 \cdot 020$ vs $0 \cdot 506 \pm 0 \cdot 021$ nmoles $\mathrm{Phe} / \mathrm{mg}$ protein.h for muscles incubated without and with insulin respectively, $P<0 \cdot 05$ ) (Fig. 1). LY 294002 markedly decreased the rate of protein synthesis detected under 


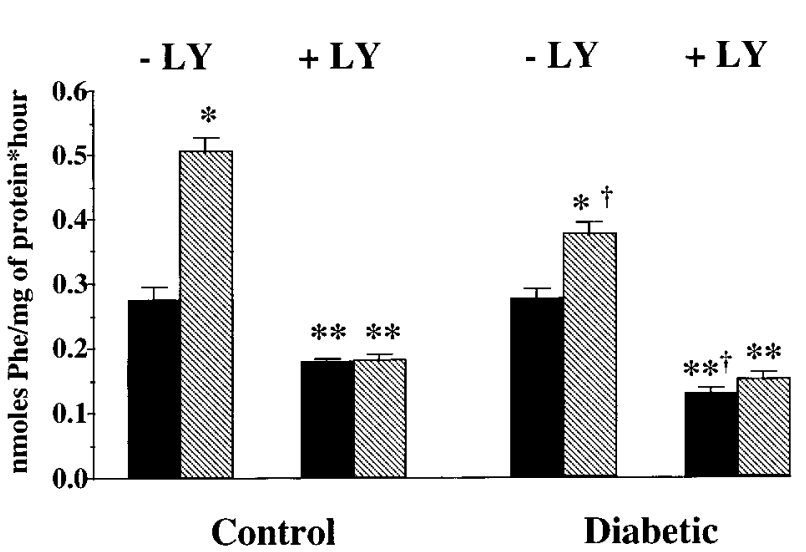

Figure 1 Effect of LY 294002 on basal (solid bars) and insulinstimulated (hatched bars) muscle protein synthesis in control and diabetic rats. Incubation was performed as described in Materials and Methods. When present, LY 294002 (LY) was added 30 min before insulin. Values represent the mean \pm S.E.M. of nine to twelve individual epitrochlearis muscles. ${ }^{*} P<0 \cdot 05$, insulin-stimulated vs basal for the same group; ${ }^{*} P<0 \cdot 05$, compared with corresponding value without inhibitor for the same group; $+P<0 \cdot 05$, difference between control and diabetic rats for the same muscle treatment.

basal conditions $(0 \cdot 178 \pm 0 \cdot 005$ nmoles $\mathrm{Phe} / \mathrm{mg}$ protein.h) and totally prevented the hormonal stimulation of protein synthesis $(0 \cdot 180 \pm 0 \cdot 010$ nmoles Phe/mg protein.h).

The basal rate of muscle protein synthesis was not altered in diabetic rats $(0 \cdot 274 \pm 0 \cdot 020$ nmoles Phe $/ \mathrm{mg}$ protein.h). Incubation with insulin also led to a significant increase in the rate of protein synthesis $(0.373 \pm$ $0 \cdot 20$ nmoles Phe $/ \mathrm{mg}$ protein.h, $P<0 \cdot 05)$. However, the magnitude of this stimulation was significantly lower than in the control group $(+36 \%$ above basal value vs $+84 \%$ respectively, $P<0 \cdot 05)$. As in the case of control muscles LY 294002 inhibited basal protein synthesis. It should be noticed, however, that the fall in basal protein synthesis was more pronounced in the diabetic than in the control group (decrease by $54 \%$ vs $35 \%$ in the controls, $P<0 \cdot 05$ ). The presence of LY 294002 in the medium containing insulin also totally blocked the stimulatory effect of the hormone on protein synthesis. It thus appeared that both in control and diabetic animals, PI-3 kinase plays a major role in the regulation of basal and insulin-stimulated protein synthesis in rat epitrochlearis muscle.

As shown in Fig. 2, insulin significantly attenuated proteolysis in control muscles $(1.57 \pm 0.07$ vs $1.10 \pm$ $0 \cdot 10$ nmoles $\mathrm{Tyr} / \mathrm{mg}$ protein.h in the absence and in the presence of insulin respectively, $P<0 \cdot 05)$. Supplementation of the medium with LY 294002 had no effect on the basal rate of protein breakdown $(1.75 \pm 0.16$ nmoles $\mathrm{Tyr} / \mathrm{mg}$ protein.h). When used in combination with insulin, this inhibitor completely reversed its antiproteolytic effect $(1.65 \pm 0 \cdot 15$ nmoles $\mathrm{Tyr} / \mathrm{mg}$ protein.h). In basal conditions, proteolysis in muscles isolated from diabetic rats was markedly elevated compared with the control group $(+30 \%, P<0 \cdot 05)$. Moreover, the rate of

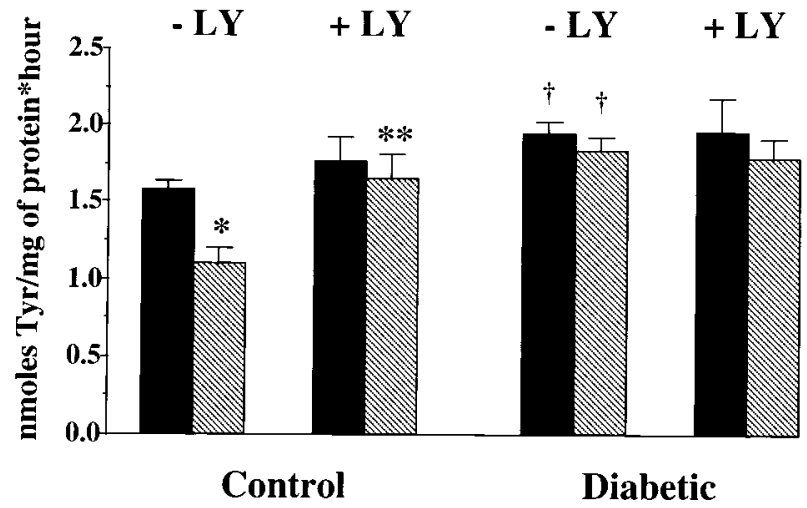

Figure 2 Effect of LY 294002 on basal (solid bars) and insulinstimulated (hatched bars) muscle proteolysis in control and diabetic rats. Incubation was performed as described in Materials and Methods. When present, LY 294002 (LY) was added $30 \mathrm{~min}$ before insulin. Values represent the mean \pm S.E.M. of seven to twelve individual epitrochlearis muscles. ${ }^{*} P<0 \cdot 05$, insulin-treated vs basal for the same group; ${ }^{*} P<0 \cdot 05$, compared with corresponding value without inhibitor for the same group; $\uparrow P<0 \cdot 05$, difference between control and diabetic rats for the same muscle treatment.

proteolysis was not affected by the availability of insulin $(2 \cdot 01 \pm 0 \cdot 11$ vs $1.83 \pm 0.09$ nmoles $\mathrm{Tyr} / \mathrm{mg}$ protein.h in the absence and presence of insulin respectively), indicating total resistance to the antiproteolytic action of the hormone. LY 294002 was without significant effect on the rate of proteolysis in both the absence $(1.95 \pm 0.23$ nmoles $\mathrm{Tyr} / \mathrm{mg}$ protein.h) and the presence $(1.78 \pm 0.14$ nmoles $\mathrm{Tyr} / \mathrm{mg}$ protein.h) of insulin.

In order to verify whether the observed changes in insulin action in vitro result from diabetes-associated insulin deficiency and not from the effect of STZ per se, an additional experiment was performed in which diabetic rats underwent insulin replacement by exogenous insulin (Table 1). Because impairment of insulin-stimulated protein synthesis as well as resistance to the antiproteolytic action of the hormone in vitro could be prevented by insulin therapy, the changes may be attributable to insulin deficiency rather than toxicity of STZ.

\section{Effect of rapamycin on insulin-regulated muscle protein turnover}

Addition of rapamycin to the incubation medium did not significantly modify the basal rate of protein synthesis both in control and diabetic muscles (Fig. 3). The stimulatory effect of insulin on protein synthesis was still detected in the presence of rapamycin. In the case of control muscles, protein synthesis activation amounted to $64 \%$ of the value detected in the absence of the inhibitor (as reflected by the increment above basal: 0.170 and 0.109 nmoles Phe $/ \mathrm{mg}$ protein.h measured without and with rapamycin respectively). In other words, 36\% of overall insulin-stimulated protein synthesis may be 
Table 1 Effect of diabetes and insulin treatment on protein metabolism in rat epitrochlearis muscle. Values represent the mean \pm S.E.M. of five individual epitrochlearis muscles

\begin{tabular}{|c|c|c|c|c|}
\hline & \multicolumn{2}{|c|}{$\begin{array}{l}\text { Protein synthesis } \\
\text { (nmoles Phe/mg protein.h) }\end{array}$} & \multicolumn{2}{|c|}{$\begin{array}{l}\text { Protein breakdown } \\
\text { (nmoles Tyr/mg protein.h) }\end{array}$} \\
\hline & Basal & Insulin & Basal & Insulin \\
\hline \multicolumn{5}{|l|}{ Group } \\
\hline Control & $0 \cdot 237 \pm 0.007$ & $0 \cdot 437 \pm 0.045$ & $2 \cdot 00 \pm 0 \cdot 14$ & $1 \cdot 45 \pm 0.09^{* *}$ \\
\hline Diabetic & $0 \cdot 232 \pm 0.019$ & $0.363 \pm 0.018^{*}$ & $2 \cdot 22 \pm 0 \cdot 16$ & $1.92 \pm 0.08^{*}$ \\
\hline Diabetic + insulin & $0 \cdot 225 \pm 0.011$ & $0 \cdot 405 \pm 0.013^{* *}$ & $1 \cdot 84 \pm 0.05^{* *}$ & $1 \cdot 46 \pm 0.08^{*}$ \\
\hline
\end{tabular}

Rats were rendered diabetic with STZ, as described in Materials and Methods. One unit Ultratard HMge insulin was then injected subcutaneously each morning and even ing, except for the last injection ( $2 \mathrm{~h}$ before killing) when Lente MC insulin was used. This protocol of insulin treatment completely normalized the plasma glucose levels of the animals (not shown). Protein synthesis and breakdown was measured in incubated epitrochlearis muscles.

${ }^{*} P<0 \cdot 05$ vs control; ${ }^{* *} P<0 \cdot 05$ vs untreated diabetic.

attributed to the rapamycin-dependent pathway. In comparison with the control group, insulin-stimulated protein synthesis in muscles from diabetic rats was more profoundly attenuated by the presence of rapamycin, as it represents only $32 \%$ of the value recorded in the absence of inhibitor (demonstrated by increment above basal of 0.060 and 0.019 nmoles Phe/mg protein.h without and with addition of rapamycin respectively). The main portion $(68 \%)$ of insulin action could be attributed to the rapamycin-dependent pathway in this case. These results indicate that the rapamycin-sensitive pathway plays a more important role in the insulin-stimulated muscle protein synthesis of diabetic rats compared with the control rats. The presence of rapamycin in the incubation medium failed to modify the rate of protein breakdown under any experimental conditions (data not shown), suggesting that

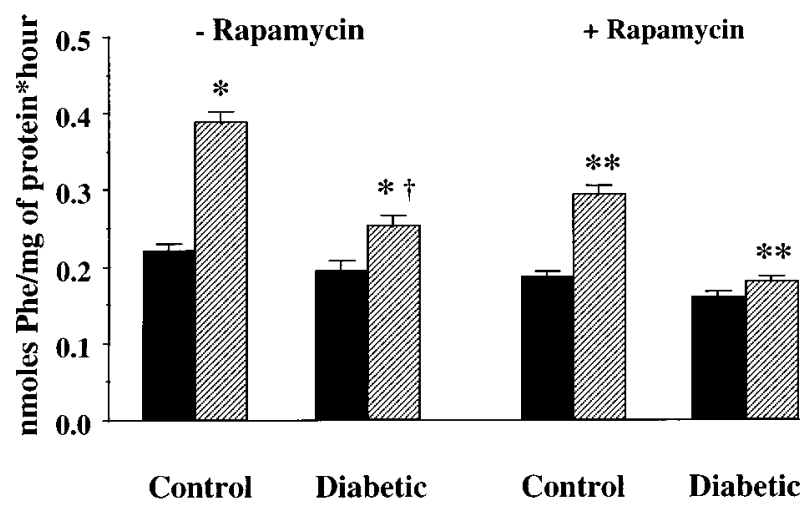

Figure 3 Effect of rapamycin on basal (solid bars) and insulinstimulated (hatched bars) muscle protein synthesis in control and diabetic rats. Data for the absence of inhibitor represent new experiments paired with the rapamycin treatment. Values represent the mean \pm S.E.M. of eight to twelve individual epitrochlearis muscles. ${ }^{*} P<0 \cdot 05$, insulin-stimulated vs basal for the same group; ${ }^{* *} P<0 \cdot 05$, compared with corresponding value without inhibitor for the same group; $\uparrow P<0 \cdot 05$, difference between control and diabetic rats for the same muscle treatment. the rapamycinsensitive pathway is not involved in the regulation of proteolysis in epitrochlearis muscle.

Basal and insulin-stimulated $p 70^{\text {S6K }}$ activity

When extracted from untreated muscles and subjected to SDS-PAGE, the $\mathrm{p} 70^{\mathrm{S} 6 \mathrm{~K}}$ appeared as a single band of apparent molecular mass $70 \mathrm{kDa}$ (Fig. 4, top). Activation of $\mathrm{p} 70^{\mathrm{S} 6 \mathrm{~K}}$ caused by multiple phosphorylation results in several phosphorylated forms that exhibit decreased
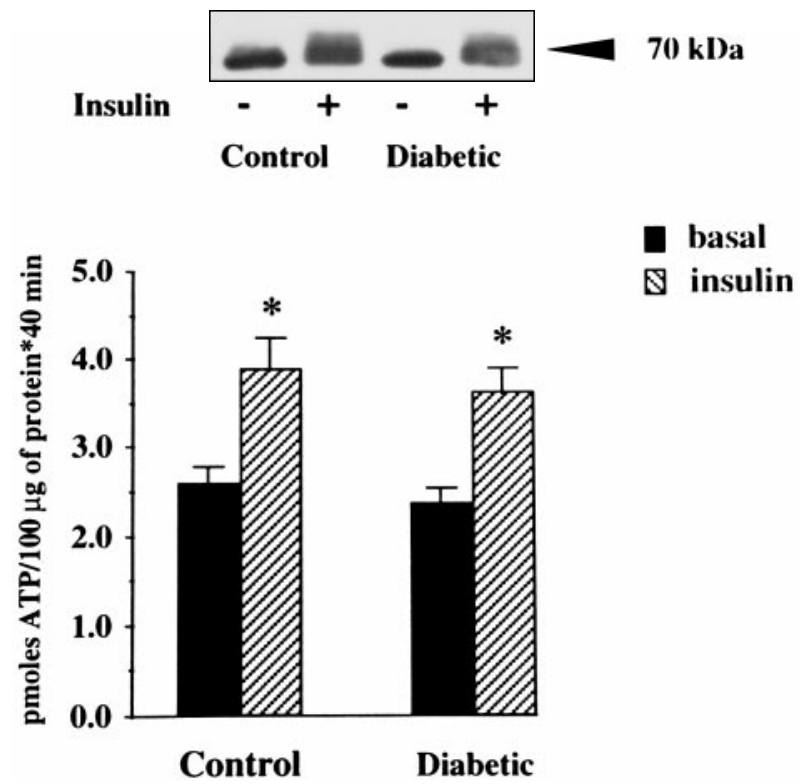

Figure 4 Insulin stimulation of $\mathrm{p} 70^{\mathrm{S6K}}$ in epitrochlearis muscles of control and diabetic rats. (Top) Western blot analysis was performed as described in Materials and Methods. Presented data are representative of three separate experiments. (Bottom) The results of the immune kinase assay are expressed as the mean \pm S.E.M. of ten to twelve individual muscles. ${ }^{*} P<0 \cdot 05$, insulin-stimulated vs basal for the same group. 
electrophoretic mobility (Chung et al. 1994). Treatment of muscles with insulin led to the gel mobility retardation of $\mathrm{p} 70^{\mathrm{S} 6 \mathrm{~K}}$ indicating its phosphorylation and activation.

There were no differences between control and diabetic rats regarding the quantity of $\mathrm{p} 70^{\mathrm{S} 6 \mathrm{~K}}$ protein, as well as the basal p $70^{\mathrm{S} 6 \mathrm{~K}}$ activity $(2.59 \pm 0.20$ and $2.35 \pm 0.19$ pmoles $\mathrm{ATP} / 100 \mu \mathrm{g}$ protein $40 \mathrm{~min}$ respectively) in the epitrochlearis muscles. Consistent with the results from the bandshift experiments, the immune complex kinase assay showed that the $\mathrm{p} 70^{\mathrm{S} 6 \mathrm{~K}}$ activation by insulin was similar in both experimental groups $(3.89 \pm 0.37$ and $3.61 \pm$ $0 \cdot 29$ pmoles ATP $/ 100 \mu \mathrm{g}$ protein 40 min for control and diabetic rats respectively).

\section{Discussion}

The diabetes-associated muscle atrophy is a consequence of both decreased protein synthesis and increased protein degradation. Several lines of evidence showed that muscle protein synthesis in diabetic rats is markedly reduced, especially in fast-twitch muscle, and that this effect is attributed to an impairment of peptide chain initiation (Flaim et al. 1980, Pain et al. 1983). Elevated proteolysis has already been claimed in skeletal muscle of diabetic rats (Pepato et al. 1996, Bailey et al. 1997). It appeared that enhanced protein breakdown in skeletal muscle observed during acute phase of diabetes results from activation of the ATP-dependent proteolytic system (Pepato et al. 1996, Bailey et al. 1997).

In the present study, the basal rate of muscle protein synthesis estimated in vitro was not altered in diabetic rats. However, the extent of protein synthesis activation by insulin was markedly reduced in diabetic muscles $(-60 \%$, as reflected by the increment above basal value), when compared with the control group. In other words, 3-day STZ-diabetic rats have developed insulin resistance which cannot be overcome by adding surplus insulin in vitro. This impaired responsiveness of muscle protein synthesis to insulin in vitro is consistent with the diabetes-associated decrease in protein synthesis in skeletal muscle, observed in numerous in vivo studies.

As expected, supplementation of insulin in vitro significantly diminished the rate of proteolysis in control epitrochlearis muscle. In diabetic rats, basal proteolysis was not only elevated compared with the controls, but it was also unaffected by availability of insulin in vitro, indicating an insensitivity to the antiproteolytic action of this hormone. Thus, it is clear that the resistance to the anabolic effect of insulin, along with insulin deficiency, facilitates muscle wasting during diabetes.

Until now, the mechanism underlying insulin resistance has not been adequately explored. A reduction in the receptor kinase activity seems to be insufficient to explain this phenomenon and might be challenged by a number of studies showing that: (i) in STZ-diabetic rats a decrease in insulin secretion is accompanied by an increased insulin binding in adipose tissue, liver, muscles, and kidney (see Sechi et al. 1992, for review); (ii) the level of the IRS-1 protein is higher in liver of diabetic rats and only slightly diminished in muscles; the latter does not explain insulin resistance, because (iii) after acute insulin stimulation in vivo, IRS-1 phosphorylation is several-fold higher and markedly prolonged, compared with the controls (Giorgino et al. 1992, Saad et al. 1992). Recent work has suggested the role of tumour necrosis factor- $\alpha$ (TNF- $\alpha$ ) interaction with the insulin transduction cascade in inducing insulin resistance (Feinstein et al. 1993, Hotamisligil et al. 1994). In STZ-diabetes accompanied by a high rate of lipolysis, elevated production of TNF- $\alpha$ by adipocytes scattered through the muscle tissue could lead to increased insulin receptor dephosphorylation as well as decreased IRS-1 activity via serine phosphorylation. These effects could account for impaired insulin sensitivity modifying different signalling pathways. A 3-day-period of diabetes in the present experiment allows sufficient exposure to TNF- $\alpha$ to result in alterations in insulin action. In contrast, short-term (few hours) treatment of rat soleus muscles with TNF- $\alpha$ in vitro had no inhibitory effect on either early steps of insulin signal transduction or glucose transport (Nolte et al. 1998).

We have demonstrated that pretreatment of muscles with LY 294002, the specific inhibitor of PI-3 kinase, completely prevented both the stimulatory effect of insulin on protein synthesis and the antiproteolytic action of this hormone in control muscles, confirming the welldescribed role of PI-3 kinase in several metabolic effects exerted by insulin in skeletal muscles (Le MarchandBrustel et al. 1995, Dardevet et al. 1996, Jullien et al. 1996, Shepherd et al. 1997). Since PI-3 kinase represents one of the early events in insulin action, it might be considered as a potential element involved in insulin resistance. Indeed, several lines of evidence indicate that attenuated responsiveness to insulin observed in non-insulin-dependent diabetes mellitus (NIDDM) (Bjornholm et al. 1997), gold thioglucose-induced obesity (Heydrick et al. 1993), as well as after glucocorticoid administration (Saad et al. 1993), may be, at least partially, explained by the impairment of the PI-3 kinase/IRS-1 association/activation.

It should be noticed, however, that NIDDM, obesity and treatment with glucocorticoids are associated with hyperinsulinaemia and, thus, the alterations in the insulin transduction system which occur in these insulin-resistant states cannot be directly compared with the conditions of insulin deficiency. Instead, the opposite regulation of IRS-1-associated PI-3 kinase activity by insulin in hyperinsulinaemic and hypoinsulinaemic states has already been documented by Folli et al. (1993). Whereas, in skeletal muscle and liver tissue of hyperinsulinaemic $o b / o b$ mice insulin-mediated PI-3 kinase activity was profoundly impaired, in tissues of STZ-diabetic rats insulin-mediated PI-3 kinase/IRS association was markedly higher, relative 
to control animals. Although the PI-3 kinase activity was not measured in our study and thus its potential alteration cannot be excluded, taking into account the results obtained with LY 294002 it becomes clear, that also in diabetic rats this kinase mediates overall stimulation of muscle protein synthesis exerted by insulin. Thus, the insulin resistance observed in STZ-treated rats is probably due to impairment of the element(s) lying downstream and dependent on PI-3 kinase.

In fact, PI-3 kinase is usually considered as one of the initial steps in the mammalian target of rapamycin (mTOR) pathway (Chung et al. 1994). Moreover, it has already been reported that the effects of insulin on increasing the synthesis of glycogen and protein in rat skeletal muscle, two of the most important actions of the hormone, involve a rapamycin-dependent input (Azpiazu et al. 1996). In the present experiments, rapamycin did not modify the basal rate of muscle protein synthesis either in control or in diabetic rats. Furthermore, this inhibitor only attenuated but did not abolish the stimulatory action of insulin in control muscles, confirming the well-established concept that the inhibition of protein synthesis exerted by rapamycin is incomplete. Indeed, in the cell culture system rapamycin has been shown to have only a partial inhibitory influence on the serum-stimulated protein synthesis, despite the fact that this drug blocks, at least in part, three of the main regulatory mechanisms controlling translation in animal cells. One of them may be the phosphorylation of ribosomal protein S6, since it appears to lie in the ribosome's mRNA binding site (Ferrari \& Thomas 1994). Likewise, phosphorylation of the translational repressor PHAS-I (also known as 4E-BP1) is rapamycin-dependent (Beretta et al. 1996). Finally, the dephosphorylation and consequent activation of elongation factor eEF-2 in response to insulin involves a rapamycin-sensitive mechanism (Redpath et al. 1996). The limited effect of rapamycin may reflect the fact that both S6 protein (or p70 S6 kinase) and PHAS-I regulate primarily cap-dependent translation rather than the overall rate of translation (Jefferies et al. 1994, Terada et al. 1994, Mendez et al. 1996, Pedersen et al. 1997). Furthermore, another protein of the $40 \mathrm{~S}$ ribosomal subunit, S17, is subjected to rapamycinsensitive phosphorylation, and probably plays a role in the regulation of translation of specific mRNAs (Patel et al. 1996).

Interestingly, the signalling model in which PI-3 kinase acts as an upstream regulator of mTOR has been challenged by a recent finding showing that the function of mTOR is directly inhibited by wortmannin and LY 294002 (Brunn et al. 1996). Indeed, such an observation provides a plausible explanation for the parallel effects of rapamycin, wortmannin and LY 294002 on certain cellular processes. On the other hand, it might question the interpretation of earlier data obtained with these PI-3 kinase inhibitors. In the present study, however, LY 294002 and rapamycin exhibited quantitatively distinct effects on insulin-stimulated muscle protein synthesis (complete vs partial inhibition). It suggests that even if total blockage of insulin action by LY 294002 occurs partially via direct mTOR inhibition, other signalling components are involved. These components are sensitive to LY 294002, but mTOR-independent. Regarding skeletal muscle, Azpiazu et al. (1996) have recently shown that in rat diaphragm incubated in vitro, basal activity of $\mathrm{p} 70^{\mathrm{S} 6 \mathrm{~K}}$ and the phosphorylation state of PHAS-I were not affected by rapamycin. In the presence of the drug, insulinstimulated PHAS-I phosphorylation was markedly diminished, but not abolished. The above observations again suggest the presence of further, insulin-activated but rapamycin-independent pathway(s) mediating a high portion of the stimulation of protein synthesis. Interestingly, these potential intermediate signalling events, bypassing rapamycin-sensitive input, are likely to be altered during diabetes because, in the present study, the insulinstimulated muscle protein synthesis was more profoundly impaired by rapamycin in diabetic rats than in the controls. It means that the rapamycin-dependent mechanism, which in control conditions makes a quantitatively minor contribution in insulin-regulated protein synthesis, becomes more important when other signalling pathways have been suppressed. In fact, a similar phenomenon has already been described by Chang et al. (1995). In their study, rapamycin was apparently unable to inhibit the insulin stimulation of glycogen synthase in normal mice. However, in mutant insulin-receptor-transgenic mice, when mitogen activating protein (MAP) kinase and RSK2 activation were defective, the insulin-stimulated increment in glycogen synthase fractional velocity was partially reduced by this drug.

Although in diabetic rats the rapamycin-sensitive pathway is essential for insulin-mediated muscle protein synthesis, diabetes-associated alterations of this pathway have recently been reported. It is well known that insulinpromoted phosphorylation of PHAS-I decreases its affinity for eukaryotic initiation factor 4E (eIF-4E) (Lin et al. 1994, Azpiazu et al. 1996, Kimball et al. 1997), allowing the initiation factor to interact with other subunits of the eIF-4F complex and mediate translation initiation. According to Kimball et al. (1996), neither quantity of eIF-4E nor the ability of this protein to bind to the mRNA cap was altered in muscle of alloxan-diabetic rats. Interestingly, diabetes markedly increased the association of PHAS-I with eIF-4E, an effect which was completely reversed within $2 \mathrm{~h}$ after treatment with insulin. Even if the above results provide an explanation for diabetesassociated impairment of translation initiation, it is evident that this mechanism does not account for insulin resistance.

Neither basal nor insulin-stimulated $\mathrm{p} 70^{\mathrm{S} 6 \mathrm{~K}}$ activity were modified in muscle of diabetic rats. It is actually known that multiple signalling inputs are implicated in the activation of $\mathrm{p} 70^{\mathrm{S} 6 \mathrm{~K}}$ (Pullen \& Thomas 1997), and that some of them are rapamycin-insensitive (Weng et al. 1995, 
Dennis et al. 1996). In fact, two different protein kinases, 3 -phosphoinositide-dependent protein kinase 1 and 2 (PDK 1 and 2) have recently been proposed to phosphorylate $\mathrm{Thr}^{389}$ and $\mathrm{Thr}^{229}$, the sites essential for full activation of $\mathrm{p} 70^{\mathrm{S} 6 \mathrm{~K}}$ (Downward 1998, Pullen et al. 1998). However, the finding that insulin-promoted $\mathrm{p} 70^{\mathrm{S} 6 \mathrm{~K}}$ is not altered during diabetes, allows the exclusion of the signalling components leading to the activation of this kinase as being responsible for insulin resistance.

Although the mechanism of insulin resistance still remains to be clarified, the presented data provide new insights into the regulation of muscle protein synthesis during diabetes. Based on current results we conclude that: (i) PI-3 kinase is required for insulin-stimulated muscle protein synthesis in diabetic rats; (ii) neither basal nor insulin-stimulated $\mathrm{p} 70^{\mathrm{s} 6 \mathrm{~K}}$ activity in skeletal muscle are modified during diabetes and thus this kinase does not account for insulin resistance; (iii) the rapamycin-sensitive pathway makes a relatively greater contribution to the stimulatory effect of insulin on muscle protein synthesis in diabetic rats than in control rats, presumably due to alterations in other insulin-activated intermediates during diabetes.

Further signalling molecules involved in insulinmediated muscle protein synthesis await determination as they are likely to account for insulin resistance. Keeping in mind that PI-3 kinase is necessary for transmission of the overall stimulatory effect of insulin, these potential elements are probably activated by insulin in a PI-3 kinasedependent manner. However, current results obtained with LY 294002 under basal conditions suggest the presence of signalling pathway(s), in addition to those occurring via PI-3 kinase (e.g. MAP kinase), also implicated in the regulation of muscle protein synthesis.

\section{Acknowledgements}

Dr K Grzelkowska is a recipient of a INRA grant to work in the Laboratoire du Métabolisme Azoté, INRA.

\section{References}

Azpiazu I, Saltiel AR, DePaoli-Roach AA \& Lawrence JC JR 1996 Regulation of both glycogen synthase and PHAS-I by insulin in rat skeletal muscle involves mitogen-activated protein kinaseindependent and rapamycin-sensitive pathways. Journal of Biological Chemistry 271 5033-5039.

Bailey JL, Price SR, England BK, Jurkovitz C, Wang X, Ding X \& Mitch WE 1997 Signals regulating accelerated muscle protein catabolism in uremia. Mineral and Electrolyte Metabolism 23 198-200.

Beretta L, Gingras A-C, Svitkin YV, Hall MN \& Sonenberg N 1996 Rapamycin blocks the phosphorylation of 4E-BP1 and inhibits cap-dependent initiation of translation. EMBO Journal 15 658-664.

Bjornholm M, Kawano Y, Lehtihet M \& Zierath JR 1997 Insulin receptor substrate-1 phosphorylation and phosphatidylinositol 3-kinase activity in skeletal muscle from NIDDM subjects after in vivo insulin stimulation. Diabetes 46 524-527.
Block NE, Komoui K, Robinson KA, Dutton SL, Lam CF \& Buse HG 1991 Diabetes-associated impairment of hepatic insulin receptor tyrosine kinase activity: a study of mechanisms. Endocrinology 128 312-322.

Brunn GJ, Williams J, Sabers C, Wiederrecht G, Lawrence JC Jr \& Abraham RT 1996 Direct inhibition of the signaling functions of the mammalian target of rapamycin by the phosphoinositide kinase inhibitors, wortmannin and LY294002. EMBO Journal 15 5256-5267

Chang P-Y, Le Marchand-Brustel Y, Cheatham LA \& Moller DE 1995 Insulin stimulation of mitogen-activated protein kinase, $\mathrm{p} 90^{\mathrm{rk}}$, and p70 S6 kinase in skeletal muscle of normal and insulin-resistant mice. Implications for the regulation of glycogen synthase. Journal of Biological Chemistry 270 29928-29935.

Chung J, Grammer TC, Lemon KP, Kazlauskas A \& Blenis J 1994 PDGF- and insulin-dependent $\mathrm{pp} 70^{\mathrm{S} 6 \mathrm{~K}}$ activation mediated by phosphatidylinositol-3-OH kinase. Nature 370 71-75.

Dardevet D, Sornet C, Attaix D, Baracos VE \& Grizard J 1994 Insulin-like growth factor-I and insulin resistance in skeletal muscles of adult and old rats. Endocrinology 134 1475-1484.

Dardevet D, Sornet C, Vary T \& Grizard J 1996 Phosphatidylinositol 3-kinase and p70 S6 kinase participate in the regulation of protein turnover in skeletal muscle by insulin and insulin-like growth factor-I. Endocrinology 137 4087-4094.

Dennis PB, Pullen N, Kozma SC \& Thomas G 1996 The principal rapamycin-sensitive $\mathrm{p} 70^{\mathrm{S} 6 \mathrm{~K}}$ phosphorylation sites, T-229 and $\mathrm{T}-389$, are differentially regulated by rapamycin-insensitive kinase kinases. Molecular and Cellular Biology 16 6242-6251.

Downward J 1998 Lipid-regulated kinases: some common themes at last. Science $279673-674$.

Feinstein R, Kanety H, Papa MZ, Lunenfeld B \& Karasik A 1993 Tumor necrosis factor- $\alpha$ suppresses insulin-induced tyrosine phosphorylation of insulin receptor and its substrates. Journal of Biological Chemistry 268 26055-26058.

Ferrari S \& Thomas G 1994 S6 phosphorylation and the $\mathrm{p} 70^{\mathrm{S} 6 \mathrm{k}} / \mathrm{p} 85^{\mathrm{S} 6 \mathrm{k}}$. Critical Reviews in Biochemistry and Molecular Biology $29385-413$

Flaim KE, Copenhaver ME \& Jefferson LS 1980 Effects of diabetes on protein synthesis in fast- and slow-twitch rat skeletal muscle. American Journal of Physiology 239 E88-E95.

Folli F, Saad MJA, Backer JM \& Kahn CR 1993 Regulation of phosphatidylinositol 3-kinase activity in liver and muscle of animal models of insulin-resistant and insulin-deficient diabetes mellitus. Journal of Clinical Investigation 92 1787-1794.

Fulks RM, Li JB \& Goldberg AL 1975 Effects of insulin, glucose, and amino acids on protein turnover in rat diaphragm. Journal of Biological Chemistry 250 290-298.

Giorgino F, Chen J-H \& Smith RJ 1992 Changes in tyrosine phosphorylation of insulin receptors and a 170000 molecular weight nonreceptor protein in vivo in skeletal muscle of streptozotocininduced diabetic rats: effects of insulin and glucose. Endocrinology $1301433-1444$.

Heydrick SJ, Julien D, Gautier N, Tanti JF, Giorgetti S, Van Obberghen E \& LeMarchand-Brustel Y 1993 Defect in skeletal muscle phosphatidylinositol 3-kinase in obese insulin-resistant mice. Journal of Clinical Investigation 91 1358-1366.

Hotamisligil GS, Budavari A, Murray DL \& Speigelman BM 1994 Reduced tyrosine kinase activity of the insulin receptor in obesity-diabetes: central role of tumor necrosis factor- $\alpha$. Journal of Clinical Investigation 94 1543-1549.

Jefferies HBJ, Reinhard C, Kozma SC \& Thomas G 1994 Rapamycin selectively represses translation of the 'polypyrimidine tract' mRNA family. Proceedings of the National Academy of Sciences of the USA 91 $4441-4445$

Jullien D, Heydrick SJ, Gautier N, Van Obberghen E \& Le MarchandBrustel Y 1996 Effect of IGF-I on phosphatidylinositol 3-kinase in soleus muscle of lean and insulin-resistant obese mice. Diabetes $\mathbf{4 5}$ 869-875. 
Kadowaki TM, Kasuga M, Akanuma Y, Ezaki O \& Takaku F 1984 Decreased autophosphorylation of the insulin receptor kinase in streptozotocin-diabetic rats. Journal of Biological Chemistry 259 14208-14216.

Karinch AM, Kimball SR, Vary TC \& Jefferson LS 1993 Regulation of eukaryotic initiation factor-2B activity in muscle of diabetic rats. American Journal of Physiology 264 E101-E108.

Kimball SR, Jefferson LS, Fadden P, Haystead TAJ \& Lawrence JC Jr 1996 Insulin and diabetes cause reciprocal changes in the association of eIF-4E and PHAS-I in rat skeletal muscle. American Journal of Physiology 270 C705-C709.

Kimball SR, Jurasinski CV, Lawrence JC Jr \& Jefferson LS 1997 Insulin stimulates protein synthesis in skeletal muscle by enhancing the association of eIF-4E and eIF-4G. American Journal of Physiology 272 C754-C759.

Le Marchand-Brustel Y, Gatier N, Cormont M \& Van Obberghen E 1995 Wormannin inhibits the action of insulin but not that of okadaic acid in skeletal muscle: comparison with fat cells. Endocrinology 136 3564-3570.

Lin FA, Kong X, Haystead TAJ, Pause A, Belsham G, Sonenberg N \& Lawrence JC Jr 1994 PHAS-I as a link between mitogenactivated protein kinase and translation initiation. Science $\mathbf{2 6 6}$ 653-656.

Mendez R, Myers MG Jr, White MF \& Rhoads RE 1996 Stimulation of protein synthesis, eukaryotic translation initiation factor 4E phosphorylation, and PHAS-I phosphorylation by insulin requires insulin receptor substrate 1 and phosphatidylinositol 3-kinase. Molecular and Cellular Biology 16 2857-2864.

Nolte LA, Hansen PA, Chen MM, Schluter JM, Gulve EA \& Holloszy JO 1998 Short-term exposure to tumor necrosis factor- $\alpha$ does not affect insulin-stimulated glucose uptake in skeletal muscle. Diabetes 47 721-726.

Odedra BR, Dalal SS \& Millward DJ 1982 Muscle protein synthesis in the streptozotocin-diabetic rats. A possible role for corticosterone in the insensitivity to insulin infusion in vivo. Biochemical Journal 202 363-368.

Pain VM \& Garlick PJ 1974 Effect of streptozotocin-diabetes and insulin treatment on the rate of protein synthesis in tissues of the rat in vivo. Journal of Biological Chemistry 249 4510-4514.

Pain VM, Albertse EC \& Garlick PJ 1983 Protein metabolism in skeletal muscle, diaphragm, and heart of diabetic rats. American Journal of Physiology 245 E604-E610.

Patel HR, Terada N \& Gelfand EW 1996 Rapamycin-sensitive phosphorylation of ribosomal protein S17 by p70 S6 kinase. Biochemical and Biophysical Research Communications 227 507-512.

Pedersen S, Celis JE, Nielsen J, Christiansen J \& Nielsen FC 1997 Distinct repression of translation by wortmannin and rapamycin. European Journal of Biochemistry 247 449-456.

Pepato MT, Migliorini RH, Goldberg AL \& Kettelhut IC 1996 Role of different proteolytic pathways in degradation of muscle protein from streptozotocin-diabetic rats. American Journal of Physiology 271 E340-E347.
Pullen N \& Thomas G 1997 The modular phosphorylation and activation of $\mathrm{p} 70^{\mathrm{S} 6 \mathrm{~K}}$. FEBS Letters $41078-82$.

Pullen N, Dennis PB, Andjelkovic M, Dufner A, Kozma SC, Hemmings BA \& Thomas G 1998 Phosphorylation and activation of $\mathrm{p} 70^{\mathrm{S} 6 \mathrm{~K}}$ by PDK1. Science $279707-710$.

Redpath NT, Foulstone EJ \& Proud CG 1996 Regulation of translation elongation factor- 2 by insulin via a rapamycin-sensitive signalling pathway. EMBO Journal 15 2291-2297.

Saad MJA, Araki E, Miralpeix M, Rothenberg PL, White MF \& Kahn CR 1992 Regulation of insulin receptor substrate-1 in liver and muscle of animal models of insulin resistance. Journal of Clinical Investigation 90 1839-1849.

Saad MJA, Folli F, Kahn JA \& Kahn CR 1993 Modulation of insulin receptor, insulin receptor substrate-1, and phosphatidylinositol 3-kinase in liver and muscle of dexamethasone-treated rats. Journal of Clinical Investigation 92 2065-2072.

Sechi LA, Griffin CA, Grady EF, Grunfeld C, Kalinyak JE \& Schambelan M 1992 Tissue-specific regulation of insulin receptor mRNA levels in rats with STZ-induced diabetes mellitus. Diabetes 41 1113-1118.

Shepherd PR, Nave BT, Rincon J, Haigh RJ, Foulstone E, Proud C, Zierath JR, Siddle K \& Wallberg-Henriksson H 1997 Involvement of phosphoinositide 3-kinase in insulin stimulation of MAP-kinase and phosphorylation of protein kinase-B in human skeletal muscle: implications for glucose metabolism. Diabetologia 40 1172-1177.

Stirewalt WS \& Low RB 1983 Effects of insulin in vitro on protein turnover in rat epitrochlearis muscle. Biochemical Journal $\mathbf{2 1 0}$ 323-330.

Terada N, Patel HR, Takase K, Kohno K, Nairn AC \& Gelfand EW 1994 Rapamycin selectively inhibits translation of mRNAs encoding elongation factors and ribosomal proteins. Proceedings of the National Academy of Sciences 91 11477-11481.

Tessari P, Biolo G, Inchiostro S, Sabadin L \& Tiengo A 1992 Insulin resistance and protein metabolism. In Protein Metabolism in Diabetes Mellitus, pp 181-185. Ed KS Nair. London, UK: Smith-Gordon.

Tischler ME, Desautels M \& Goldberg AL 1982 Does leucine, leucyltRNA or some metabolite of leucine regulate protein synthesis and degradation in skeletal and cardiac muscle? Journal of Biological Chemistry 257 1613-1621.

Weng Q-P, Andrabi K, Kozlowski MT, Grove JR \& Avruch J 1995 Multiple independent inputs are required for activation of the p70 S6 kinase. Molecular and Cellular Biology 15 2333-2340.

White MF \& Kahn CH 1994 The insulin signaling system. Journal of Biological Chemistry 269 1-4.

Williams IH, Chua BHL, Sahms RH, Siehl D \& Morgan HE 1980 Effects of diabetes on protein turnover in cardiac muscle. American Journal of Physiology 239 E178-E185.

Received 8 May 1998

Accepted 11 September 1998 